\title{
Changes in the activity of citrate lyase, malic enzyme and acetyl-CoA synthetase in rat liver after short-term and long-term feeding with ethanol
}

\author{
By E. FELLENIUS, U. NISBETH, L. PIILSTRÖM AND \\ K.-H. KIESSLING \\ Alcohol Research Group, Swedish Medical Research Council, Institute of \\ Zoophysiology, University of Uppsala, Uppsala, Sweden \\ (Received 6 fuly $1972-$ Accepted 2 October 1972)
}

\begin{abstract}
I. The effect of short-term and long-term feeding $(0-80 \mathrm{~d})$ with a liquid diet containing ethanol on the activity of rat hepatic enzymes related to lipogenesis has been evaluated. Carbohydrates were isoenergetically substituted for ethanol in the control animals.

2. The maximum concentration of triglycerides in the livers was reached after about $3 \circ \mathrm{d}$, when it was almost three times as high as in the control animals. The activity of malic enzyme (EC I.I.I.40) and ATP citrate lyase (EC 4.I.3.8) decreased significantly in the ethanol group, compared with the control rats, within Io d and remained low during the rest of the experiment $(80 \mathrm{~d})$. After $20 \mathrm{~d}$, the acetyl-COA synthetase $(E C$ 6.2.I.I) activity increased significantly in the livers of the ethanol-fed rats but fell subsequently to values similar to those in the livers of the control rats. Thus, despite a pronounced increase in the amount of triglyceride in the livers of rats on a liquid diet containing ethanol, there was a dramatic decrease in the activity of the enzymes (malic enzyme and citrate lyase) involved in lipogenesis.

3. The almost unchanged activity of acetyl-CoA synthetase shows that the utilization of acetate, produced when ethanol is oxidized, is not stimulated by long-term feeding with ethanol. The involvement of citrate lyase in various postulated shuttles for the transport of reducing equivalents across the mitochondrial membrane and the role of malic enzyme in the microsomal ethanol-oxidizing system are discussed.
\end{abstract}

The activities of malic enzyme $(E C$ I.I.I.40, L-malate:NADP oxidoreductase (decarboxylating)) and ATP citrate lyase $\left(E C_{4} \cdot 1 \cdot 3.8\right.$, ATP: citrate oxaloacetatelyase) are known to be related to the lipogenic capacity of the liver (Tepperman $\&$ Tepperman, 1964; Kornacker \& Lowenstein, 1965a). The malic enzyme is mainly concerned with the supply of NADPH for lipid biosynthesis (Shrago, Lardy, Nordlie $\&$ Foster, 1963; Wise \& Ball, 1964), whereas the citrate lyase reaction may provide extramitochondrial acetyl-CoA for the synthesis of fatty acids from carbohydrates (Bhaduri \& Srere, I963; D’Adamo \& Haft, ı965; Kornacker \& Lowenstein, 1965 $b$ ). The activation by acetyl-CoA synthetase (EC 6.2.I.I, acetate:CoA ligase (AMP)) of acetate derived from oxidation of ethanol may be an additional mechanism for supplying acetyl-CoA for hepatic lipogenesis (Lieber $\&$ Schmid, 196r).

The malic enzyme and the citrate lyase may also have other functions in the metabolic changes induced by ethanol. Thus, NADPH formed by the malic enzyme may be a cofactor in the microsomal ethanol-oxidizing system recently proposed by Lieber \& DeCarli (1970). The citrate lyase may be involved in postulated shuttles for the transport of reducing equivalents across the mitochondrial membrane (Borst, I963; Grunnet, I970; Lundquist, Thieden \& Grunnet, r97r).

The aim of this investigation was to study the effect of feeding rats with ethanol in 

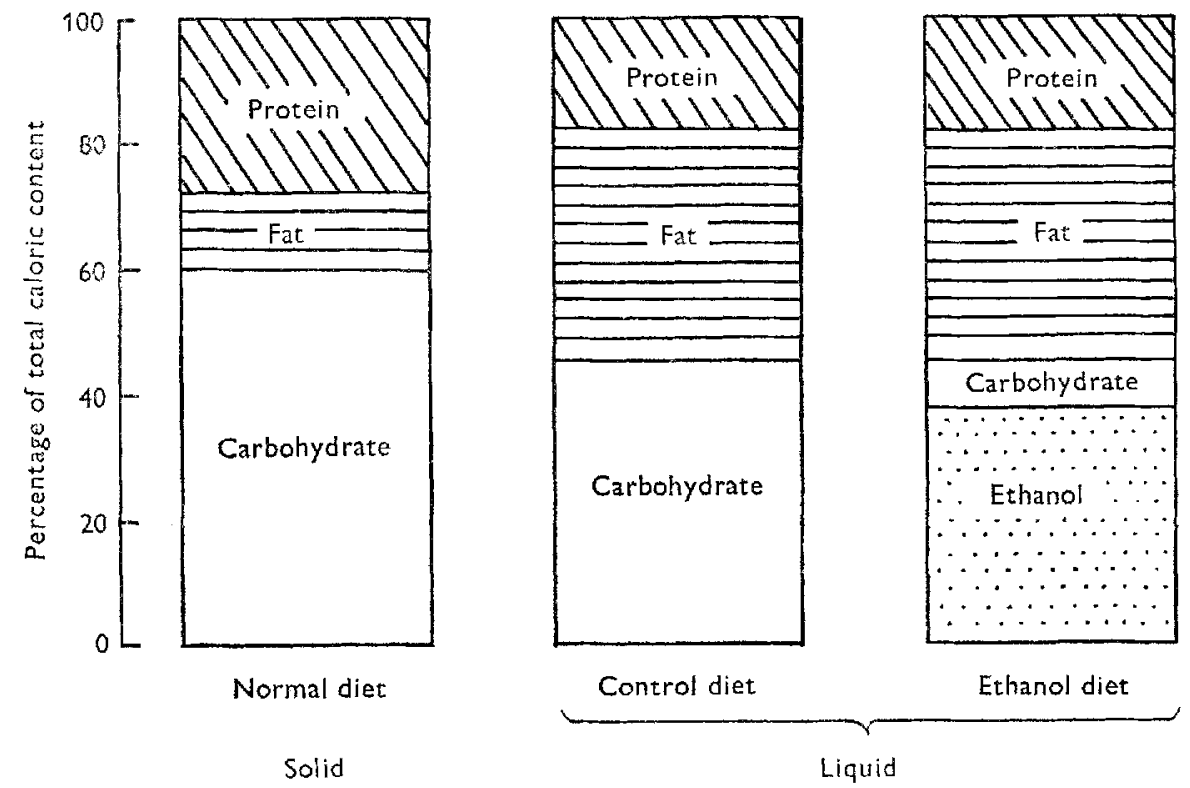

Fig. I. Composition of the diets (see also Pilström, Fellenius \& Kiessling, 1973).

a liquid diet on the activity of the enzymes involved in lipogenesis. The roles of different postulated shuttles in the transport of NADH through the mitochondrial membrane and the microsomal ethanol-oxidizing system are also discussed. A brief report on parts of this work has already been published (Fellenius, Nisbeth, Kiessling \& Pilström, I972).

\section{MATERIAL AND METHODS}

Male rats of the Wistar strain from the Institute of Zoophysiology, Uppsala, Sweden, were used. The mean age of the rats was $5^{\mathrm{r}}\left(4^{\circ}-7^{6}\right) \mathrm{d}$ at the beginning of the experiment. The animals were divided into three groups, 6-7 animals in each group. One group was fed on a commercial solid food (Purina Laboratory Chow, Astra-Ewos, Södertälje, Sweden), with water as drinking-fluid. The second group received a liquid diet without ethanol (control group). The third group was given a liquid diet containing ethanol instead of sucrose (ethanol group). The compositions of the diets are shown in Fig. I. A detailed description of the liquid diets, values for food intake and changes in body-weight during the experimental period has been given elsewhere (Pilström, Fellenius \& Kiessling, 1973). After I0, 20, 30, 40,60 and $80 \mathrm{~d}$, rats were killed and enzyme activity and total protein were determined in their livers as follows.

About $\mathrm{I} \mathrm{g}$ liver was quickly excised and homogenized in $10 \mathrm{ml}$ of ice-cold $0.25 \mathrm{M}$ sucrose-I mM ethyleneglycol-bis ( $\beta$-aminoethyl ether) $N, N^{\prime}$-tetraacetic acid (EGTA) solution $\left(\mathrm{pH}_{7} \circ\right.$ ). The triglycerides in this homogenate were quantified by the method of Eggstein \& Kreutz (1966). The rest of the homogenate was centrifuged for 5 min at $750 g_{\mathrm{av}}\left(0-4^{\circ}\right)$. After the fatty layer had been removed, the supernatant fraction 


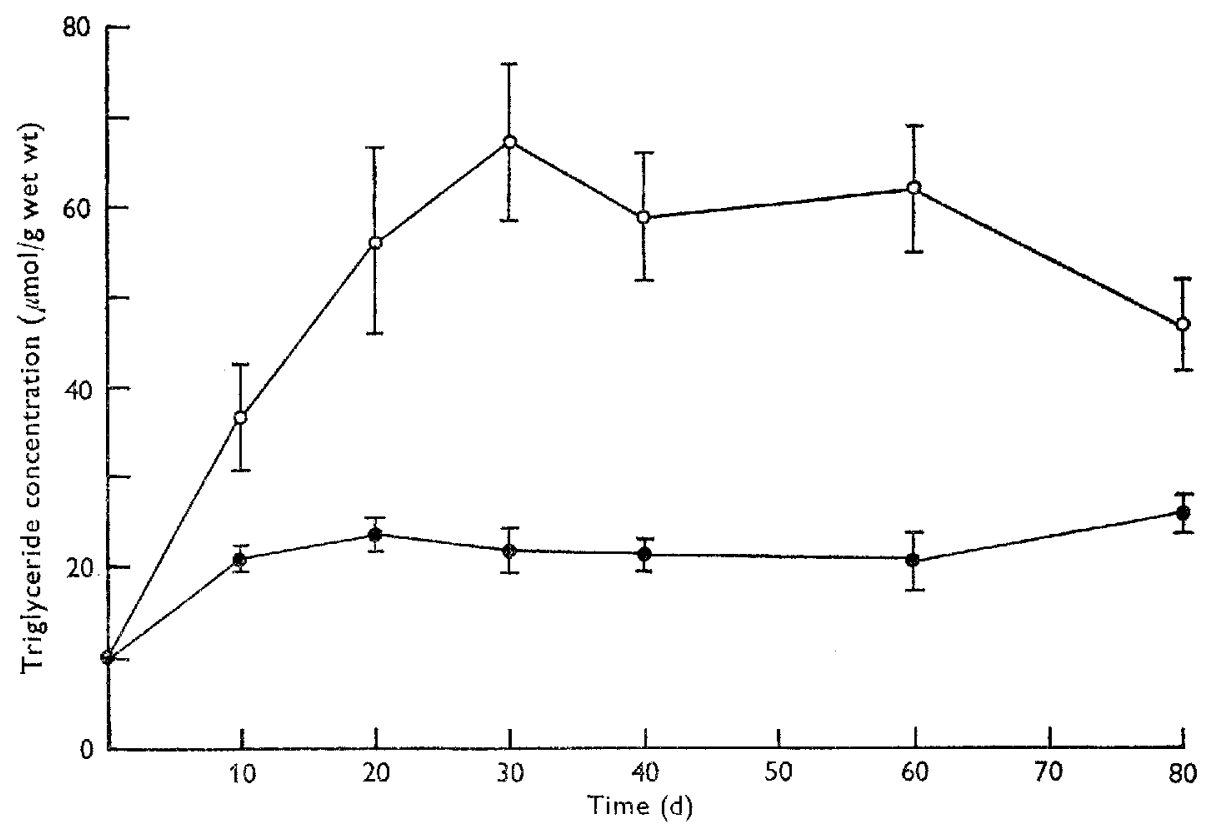

Fig. 2. Triglyceride concentration in the livers of rats fed on a liquid diet containing ethanol (O) or on a liquid control diet (e). (Mean values for six or seven animals; the vertical bars represent the standard error of the mean.)

was centrifuged for $30 \mathrm{~min}$ at $75000 \mathrm{~g}_{\mathrm{av}}\left(0-4^{\circ}\right)$. The resulting supernatant fraction was used for the determination of enzyme activities and total protein.

Malic enzyme activity was determined by the method of Hsu \& Lardy ( 1969 ). The reaction was started by the addition of enzyme and readings were taken for $5 \mathrm{~min}$ $\left(\lambda 34^{\circ} \mathrm{nm}, 25^{\circ}\right)$. The change in extinction in the sample cuvette was corrected for the change in extinction in a blank cuvette, from which L-malate was omitted.

Determinations of the activity of citrate lyase and acetyl-CoA synthetase were made by the methods of Srere \& Lipmann (1953) and Lipmann \& Tuttle (1945) respectively, as described by Kornacker \& Lowenstein $(1965 a)$. CoA was omitted from the blank cuvette. The reaction was started by the addition of enzyme. Protein concentration was in the range of $0.5-2.0 \mathrm{mg}$ per assay. The incubation was carried out for $40 \mathrm{~min}$ at $37^{\circ}$. Succinic anhydride was used as standard (Lipmann \& Tuttle, I945).

'Two or three different amounts of each enzyme were used to confirm proportionality between activity and protein concentration. Protein of the supernatant fraction was measured by the method of Bramhall, Noack, Wu \& Lowenberg (I969). The activity of malic enzyme is defined as $\mu \mathrm{mol} \mathrm{NADPH}$ formed/min per $g$ protein of the supernatant fraction. The activity of citrate lyase and acetyl-CoA synthetase are expressed as $\mu \mathrm{mol}$ acetyl-CoA formed/min per $\mathrm{g}$ protein of the supernatant fraction. The concentration of ethanol was determined by the method of Dickinson \& Dalziel (1967). 


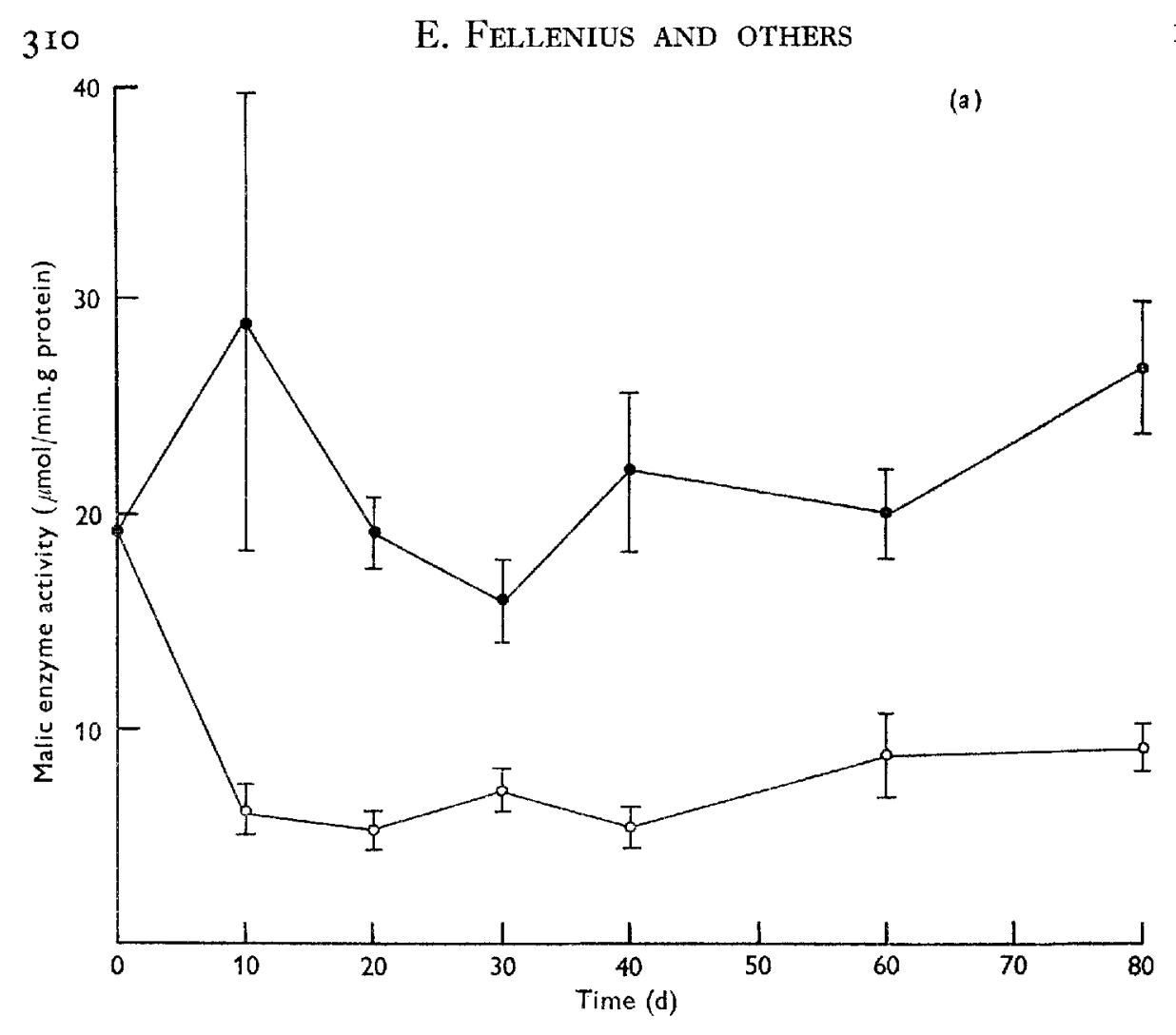

1973

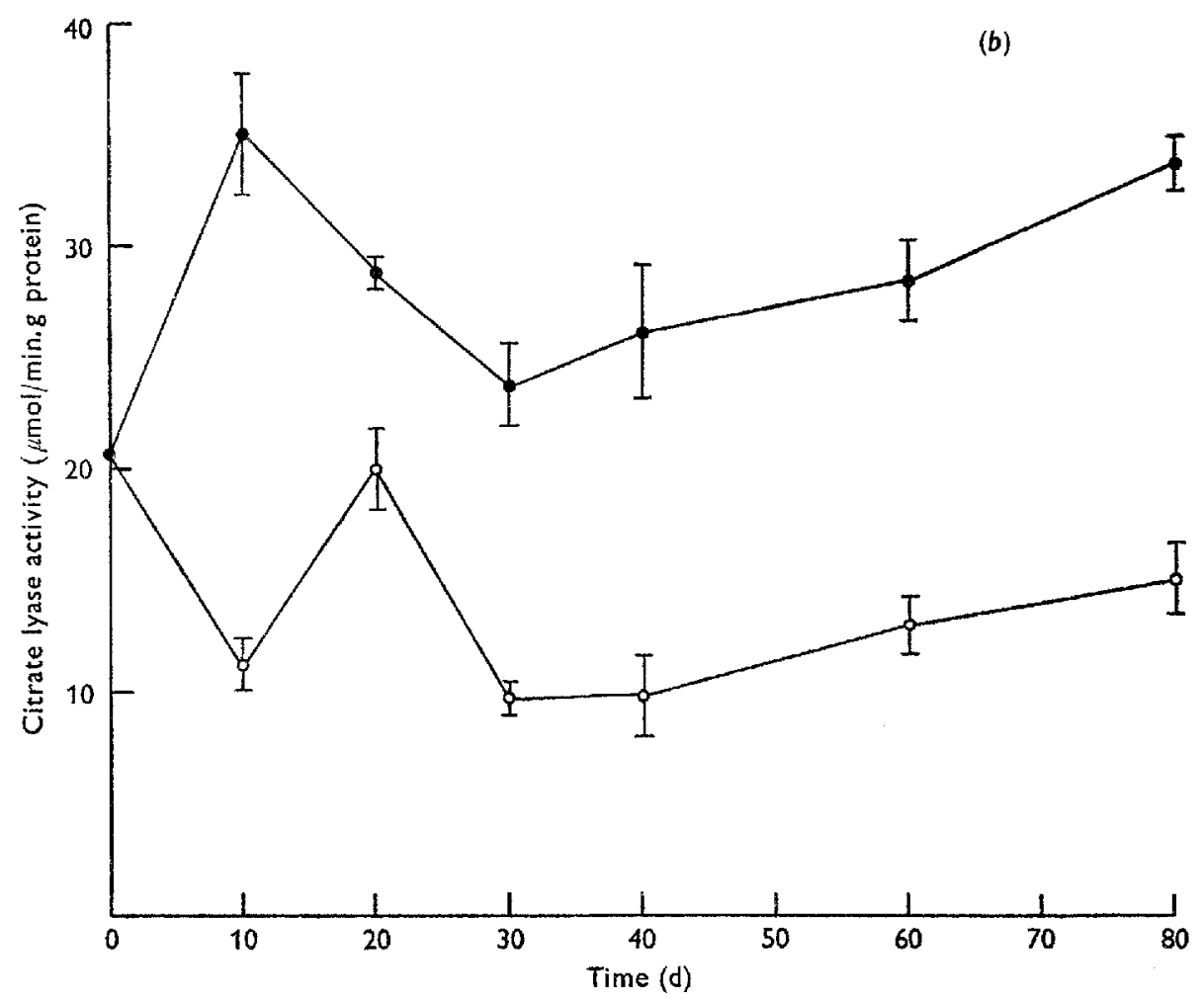

Figs. $a$ and $3 b$. For legend see facing page. 


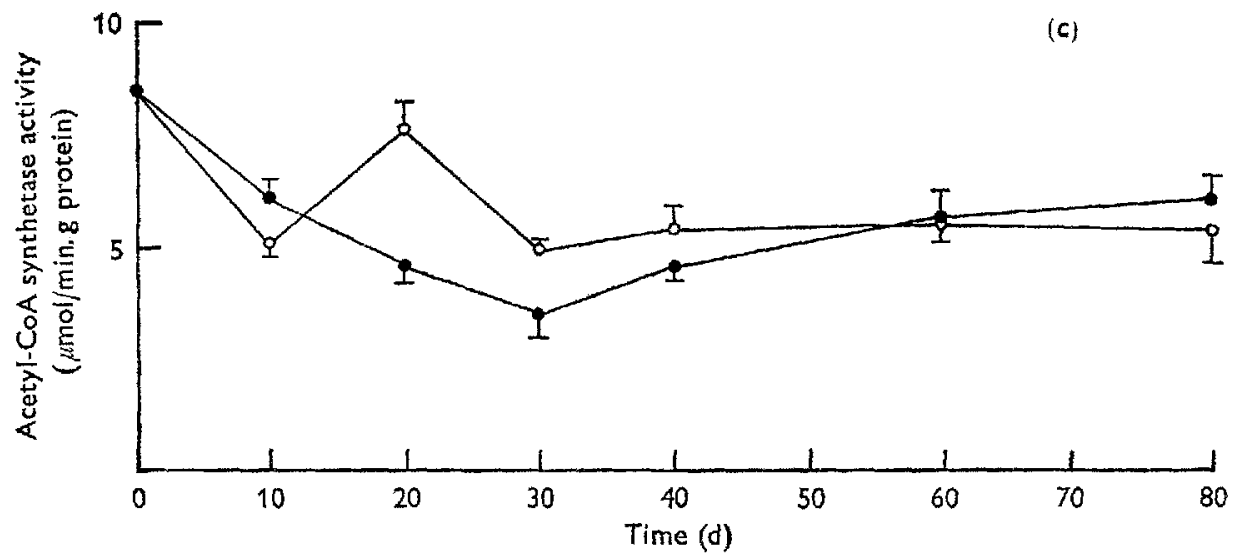

Fig. 3. Effect of feeding rats on a liquid diet containing ethanol (O) or on a liquid control diet ( ) on the hepatic activities of malic enzyme $(a)$, citrate lyase $(b)$ or acctyl-CoA synthetase $(c)$. (Mean values for six or seven rats; the vertical bars represent the standard error of the mean.)

\section{RESUI.TS}

\section{Effect of ethanol feeding on the content of triglycerides in the liver}

As illustrated in Fig. 2, the concentration of triglycerides in the livers of control animals on a liquid diet incrcased significantly $(P<0.0$ r by Student's $t$ test $)$ after Io d. After that time the level of neutral fat remained constant. The maximum concentration of triglycerides in the livers of rats on a liquid diet containing ethanol was reached after about $30 \mathrm{~d}$ and at that time was almost three times that in the control animals.

\section{Effect of ethanol feeding on the activity of malic enzyme, citrate lyase and acetyl-CoA synthetase}

After Io d, there was a dramatic decrease in the activity of malic enzyme in the rats given an ethanol-containing diet (Fig. $3 a$ ). After that time, the activity remained fairly constant.

Fig. $3 b$ illustrates the activity of citrate lyase as a function of the duration of feeding with liquid control and ethanol-containing diets. The activity in the control group varied slightly but was always greater than that in animals kept on the solid, commercial diet (o d). In the animals fed with ethanol, there was a decrease in the rate of formation of acetyl-CoA by the citrate lyase reaction. The low activity was maintained throughout the experimental period.

From Fig. 4 one may draw the conclusion that a definite relation exists between the malic enzyme and citrate lyase, which confirms the results obtained by Yeh, Leveille \& Wiley (1970). The two groups, ethanol-treated and controls, have been pooled since the regression coefficient found for each group did not differ significantly $(P>0.05)$. The correlation coefficient of 0.91 is statistically significant $(P<0.01)$, indicating a high degree of correlation between the activities of these two enzymes.

The experiment summarized in Fig. $3 c$ was performed to study the effect of ethanol 


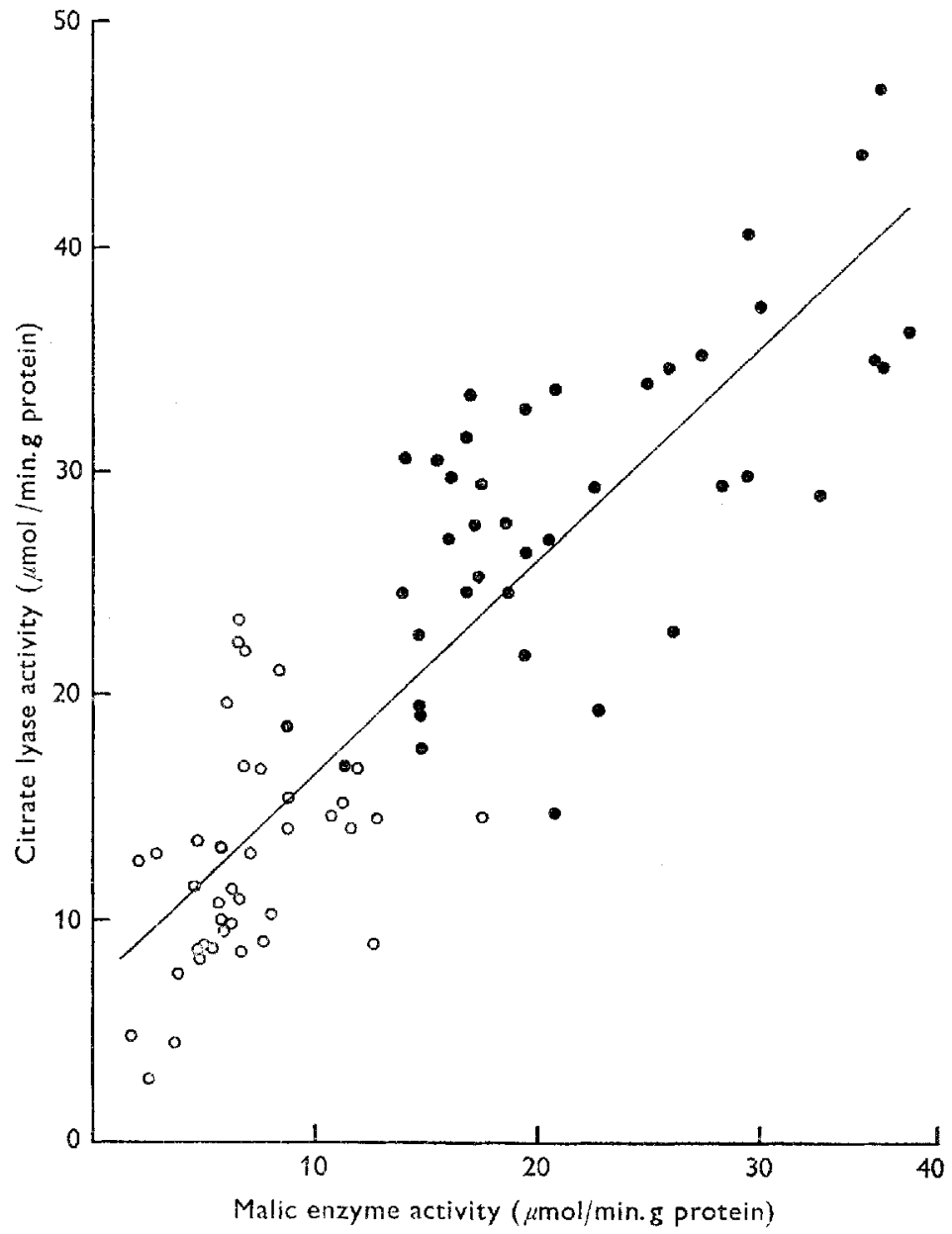

Fig. 4. Correlation of malic enzyme and citrate lyase activities ( $\mu \mathrm{mol} / \mathrm{min}$ per g protein) in the rat liver. $O$, rats on a liquid diet containing ethanol; $\boldsymbol{O}$, rats on a liquid control diet.

Table I. Influence of age on hepatic activities of malic enzyme, citrate lyase and acetyl-CoA synthetase and liver triglyceride concentration in rats on a normal solid diet

(Mean values with their standard errors; numbers of observations in parentheses)

Malic enzyme ( $\mu \mathrm{mol} / \mathrm{min}$ per $\mathrm{g}$ protein)

Citrate lyase ( $\mu \mathrm{mol} / \mathrm{min}$ per $\mathrm{g}$ protein)

Acetyl-CoA synthetase ( $\mu \mathrm{mol} / \mathrm{min}$ per g protein)

Triglyceride ( $\mu \mathrm{mol} / \mathrm{g}$ wet weight)

\begin{tabular}{rrrr}
\multicolumn{4}{c}{ Age (weeks) } \\
Mean & S.E. & \multicolumn{2}{c}{$20-22$} \\
19.3 & $1.2(7)$ & 5.9 & $0.6(5)$ \\
20.7 & $1.4(7)$ & 9.5 & $0.5(5)$ \\
8.5 & $0.7(7)$ & 5.7 & $0.3(5)$ \\
10.3 & $1.5(7)$ & 10.1 & $0.7(5)$
\end{tabular}


feeding on the activity of acctyl-CoA synthetase. There was a significant increase $(P<0.01)$ in the activity in the ethanol group after $20 \mathrm{~d}$, compared with the control animals. However, the rate fell subsequently to values similar to those in the livers of the control rats.

The enzyme activity in young rats $(7-8$ weeks) and old rats (20-22 weeks) fed on a commercial solid diet was determined to evaluate the effect of age on enzyme activity (Table I). Decreased hepatic enzyme activity was found to accompany ageing, without any change in the triglyceride content. A corresponding change with age in animals on a liquid control diet was found only with acetyl-CoA synthetase (Fig. $3 c$ ).

\section{DISCUSSION}

The triglyceride content was estimated in the livers of three groups of animals on different diets. With a liquid diet without ethanol, the triglyceride content was higher than in animals given ordinary pellets with water as the drinking-fluid (Fig. 2). This may be explained by the fact that the amount of fat in the liquid diet was higher than that in the commercial, solid food (Fig. I).

Changes in the activity of citrate lyase in animals kept on a liquid diet (Fig. $3^{b}$ ) are complex because they are affected by several factors. (I) A high-fat, low-carbohydrate diet should lead to a decreased synthesis of fatty acid and a diminished activity of citrate lyase (Kornacker \& Lowenstein, 1965a). (2) Equally significant is the chemical nature of the carbohydrates. The carbohydrates in the commercial solid diet contain polysaccharides built up mainly of glucose (S. Elvin, personal communication), whereas the liquid diet contained sucrose (fructose-glucose components). An increased activity of citrate lyase and increased lipogenic capacity has been observed in rats given fructose instead of glucose (Sullivan, Miller, Wittman \& Hamilton, 1971). (3) On solid diets there is a decline in activity with age ('Table r). The incrcase in citrate lyase with time, shown in Fig. $3^{b}$, is presumably because the positive effect of dietary sucrose is more important than the negative effect of age. Similar conclusions may apply to the changes in malic enzyme (Fig. $3 a$ ), although the changes are less marked for this enzyme. For acetyl-CoA synthetase, there is only a decline with time (Fig. 3 c), perhaps because this enzyme is not much affected by dietary changes.

The almost threefold accumulation of neutral fat in the third group, the ethanol group (Fig. 2), compared with the controls, confirms the results obtained by other authors (Best, Hartroft, Lucas \& Ridout, 1949; Mallov, 1955; Lieber, 1967). Some authors have suggested that increased hepatic synthesis of fatty acid is the main source of the lipid accumulation (Lieber \& Schmid, 1961 ; Lieber, 1967). This stimulation of fatty acid synthesis in the liver after ethanol administration is considered to be caused by an increased production of reduced NAD and acetate (acetyl-CoA) during ethanol oxidation. From the results concerning the activity of enzymes involved in lipogenesis (Fig. 3), it may be concluded that this mechanism is probably not of importance. It is generally held that a depression of hepatic lipogenesis is accompanied by a reduction in the activity of the malic enzyme and the citrate lyase (Tepper- 
man \& Tepperman, r964; Kornacker \& Lowenstein, 1965a). The results in Fig. 3 therefore indicate that fatty acid synthesis is depressed by feeding with ethanol. The relationship between lipogenesis and citrate-lyase activity under the present experimental conditions may perhaps be questioned, since the acetyl-CoA required for fatty acid synthesis may be formed by the activation of free acetate derived from the oxidation of ethanol (Lieber, 1967 ), and in this way citrate is eliminated as the main substrate. This proposal is, however, not supported by the results for the activity of acetyl-CoA synthetase (Fig. $3 \mathrm{c}$ ). The activity increased after $20 \mathrm{~d}$ in the ethanol group, but after that it decreased to the values in the livers of control rats. Moreover, the citrate lyase activity and the malic enzyme changed in a parallel fashion (Fig. 4), demonstrating their relationship.

The initial decrease in the enzyme activity of citrate lyase and malic enzyme in the ethanol-drinking group may have been due to starvation, since a decrease in both body-weight and food consumption was found (Pilström et al. 1973). Kornacker \& Lowenstein $\left(1_{96} 6_{5}\right.$ ) and Wise $\&$ Ball (1964) have reported that starvation decreases the activity of malic enzyme and citrate lyase. At about the time (15-20 d) when the rate of growth and food intake were constant in the ethanol group, the activity of citrate lyase increased suddenly (Fig. $3 b$ ). However, in spite of the very high concentration of triglyceride (Fig. 2), indicating a high rate of synthesis of neutral fat, the activity decreased again between 20 and $30 \mathrm{~d}$ after the start of the experiment.

The mechanism by which enzyme activity is altered in response to changes in lipogenesis is not clear, but it seems likely that the activity of an enzyme is related to substrate flow, as proposed by Freedland \& Harper (1958) and Fitch \& Chaikoff (1960). For malic enzyme, citrate lyase and acetyl-CoA synthetase, the substrate flow would be related to the utilization of NADPH and acetyl-CoA for fatty acid synthesis. In addition to this theory, Atkinson \& Walton (1967) and Angielski \& Szutowicz (1967) have suggested that the activity in vivo of citrate lyase may be modulated by the adenine nucleotides (AMP, ADP and ATP).

The findings of Bode, Stähler, Kono \& Goebell (1970) support our results. They suggested that fatty acid synthesis was reduced in the presence of ethanol by an inhibition of the acctyl-CoA carboxylase reaction by high concentrations of long-chain acyl-CoA. Furthermore, Olivercrona, Hernell, Johnson, Fex, Wallinder \& Sandgren (I972) recently measured fatty acid synthesis in vivo by using tritiated water as a tracer. Their results showed no stimulation by ethanol of fatty acid synthesis in the liver.

As was mentioned on p. 307 , the malic enzyme and the citrate lyase may be involved in metabolic processes other than lipogenesis during the oxidation of ethanol. Thus, NADPH formed by the malic enzyme may be a cofactor in the microsomal ethanoloxidizing system recently proposed by Lieber \& DeCarli (I970). The apparent $K_{m}$ value $(8 \mathrm{mM})$ of this system indicates that only in the presence of high concentrations of ethanol would the utilization of NADPH be so rapid as to influence the activity of malic enzyme. We estimated at 09.3 o hours the concentration of ethanol in the blood of six rats which had received the liquid diet for $30 \mathrm{~d}$. The concentrations of ethanol were ${ }_{1} 3,6,0,0,24$ and $18 \mathrm{~mm}$ respectively. The wide variations were evidently due 
to the fact that the animals had eaten at different times during the preceding night. However, the concentration of ethanol was high enough in at least thrce animals to allow more ethanol to be oxidized through the microsomal ethanol-oxidizing system. As has already been pointed out, there is no corresponding increase in the activity of malic enzyme (Fig. $3 a$ ). Thus, indirectly, our results yield no support for the existence of a microsomal ethanol-oxidizing system, which is in agreement with the results of many other authors (Klaasen, r969; Tephly, Tinelli \& Watkins, 1969; Isselbacher \& Carter, I970).

It is generally accepted that the mitochondrial membrane in the liver is impermeable to NADH (Lehninger, 195I) and several systems have been suggested to transfer the reducing equivalents formed when ethanol is oxidized from the cytoplasm to the mitochondria (Bücher \& Klingenberg, 1958; Borst, 1963; Sacktor \& Dick, 1964; Hassinen, 1967; Whereat, Orishimo, Nelson \& Phillips, 1969). Citrate lyase is probably involved in two of these shuttles. In the citrate-malate shuttle (Borst, 1963), citrate diffuses out of the mitochondria and is split by the citrate lyase reaction. The oxaloacetate that is formed is reduced and NADH is oxidized by the malate dehydrogenase. In the second system, the fatty acid elongation mechanism (Whereat $e t$ al. I969; Grunnet, 1970; Lundquist et al. $197 \mathrm{I}$ ), there must be a continuous supply of acetyl-CoA for the elongation of acyl-CoA. Normally this acetyl-CoA is mainly formed in the mitochondrial matrix and must be transferred to the outer mitochondrial membrane, where the NADH-dependent, fatty acid elongation system is located (Whereat et al. 1969). The only system of quantitative importance for the transfer of acetylCoA through the inner mitochondrial membrane is by means of citrate (Kornacker \& Lowenstein, 1965a) and a subsequent extramitochondrial splitting of the citrate by means of citrate lyase. During the oxidation of ethanol, acetyl-CoA derived from ethanol may be an additional mechanism for supplying the fatty acid elongation mechanism with acetyl-CoA.

From our results concerning the decreased activity of citrate lyase (Fig. $3 b$ ) and the almost unaffected activity of acetyl-CoA synthetase (Fig. $3 c$ ), we suggest that, when ethanol is metabolized, none of the shuttles outlined above is involved in the transport of NADH to the mitochondria.

This work was supported financially by the Swedish Medical Research Council, Grant No. B7I-12Y-2364-04.

\section{REFERENCES}

Angielski, S. \& Szutowicz, A. (1967). Abstr. 4th Mtg Fedn Eur. Biochem. Soc., Oslo p. $5^{8 .}$ Atkinson, D. E. \& Walton, G. M. (1967). F. biol. Chem. 242, 3239.

Best, C. H., Hartroft, W. S., Lucas, C. C. \& Ridout, J. H. (1949). Br. med. F. ii, Ioo .

Bhaduri, A. \& Srere, P. A. (1963). Biochim. biophys. Acta 7o, 22x.

Bode, Ch., Stähler, E., Kono, H. \& Goebell, H. (1970). Biochim. biophys. Acta 210, 448.

Borst, P. (1963). In Funktionelle und Morphologische Organization der Zelle, p. 137 [P. Karlsson, editor]. Berlin, Heidelberg and New York: Springer Verlag.

Bramhall, S., Noack, N., Wu, M. \& Lowenberg, J. R. (1969). Analyt. Biochem. 31, I46.

Bücher, T. \& Klingenberg, M. (1958). Angew. Chem. 70, $55^{2}$.

D'Adamo, A. F. Jr \& Haft, D. E. (r965). F. biol. Chem. 240, 6r3.

Dickinson, F. M. \& Dalziel, K. (1967). Biochem. F. 104, 165.

Eggstein, M. \& Kreutz, F. K. (1966). Klin. Wschr. 44, 262. 
Fellenius, E., Nisbeth, U., Kiessling, K.-H. \& Pilström, L. (r972). Proc. Nutr. Soc. 31, 37 A.

Fitch, W. M. \& Chaikoff, I. L. (1960). F. biol. Chem. 235, 554.

Freedland, R. A. \& Harper, A. E. (1958). $\mathscr{7}$. biol. Chem. 234, I350.

Grunnet, N. (1970). Biochem. biophys. Res. Commun. 4r, gog.

Hassinen, I. (1967). Annls Med. exp. Fenn. 45, 35.

Hsu, R. Y. \& Lardy, H. A. (1969). Meth. Enzymol. r3, 230.

Isselbacher, K. J. \& Carter, E. A. (1970). Biochem. biophys. Res. Commun. 39, 530.

Klaasen, C. D. ( I 969). Proc. Soc, exp. Biol. Med. 132, 1099.

Kornacker, M. S. \& Lowenstein, J. M. (1 965a). Biochem. 7. 94, 209.

Komacker, M. S. \& Lowenstein, J. M. (1965b). Biochem. F. 95, 823.

Lehninger, A. L. (1951). F. biol. Chem. ז90, 345 .

Lieber, C. S. (1967). A. Rev. Med. 18, 35 .

Lieber, C. S. \& DeCarli, L. M. (1 970). F. biol. Chem. 245, 2505 .

Lieber, C. S. \& Schmid, R. (I961). 7. clin. Invest. 40, 394.

Lipmann, F. \& Tuttle, L. C. (I945). F. biol. Chem. I59, 2 r.

Lundquist, F., Thieden, H. \& Grunnet, N. (197 ). In Metabolic Changes Induced by Ethanol, p. 108 [G. A. Martini and Ch. Bode, editors]. Berlin, Heidelberg and New York: Springer Verlag.

Mallov, S. (1955). Proc. Soc. exp. Biol. Med. 88, 246.

Olivercrona, T., Hernell, O., Johnson, O., Fex, G., Wallinder, L. \& Sandgren, O. (1972). Q. fl Stud. Alcohol 33, $\mathrm{r}$.

Pilström, L., Fellenius, E. \& Kiessling, K.-H. (1973). Br. Y. Nutr. 29, 297.

Sacktor, B. \& Dick, A. R. (1964). Science, N.Y. I45, 606.

Shrago, E., Lardy, H. A., Nordlie, R. C. \& Foster, D. O. (1963). F. biol. Chern. 238, 3188.

Srere, P. A. \& Lipmann, F. (1953). 7. Am. chem. Soc. 75, 4874 .

Sullivan, A. C., Miller, O. N., Wittman, J. S. \& Hamilton, J. G. (197r). F. Nutr. ror, 265.

Tephly, T. R., Tinelli, F. \& Watkins, W. D. (rg69). Science, N.Y. I66, 627.

Tepperman, H. M. \& Tepperman, J. (1964). Am. F. Physiol. 206, 357.

Whereat, A. F., Orishimo, M. W., Nelson, J. \& Phillips, S. J. (1969). 7. biol. Chem. 244, 6498.

Wise, E. M. Ir \& Ball, E. G. (1964). Proc. Natn. Acad. Sci. U.S.A. 52, 1255.

Yeh, Y.-Y., Leveille, G. A. \& Wiley, J. H. (1970). J. Nutr. xoo, 917. 